\title{
China pledges 12 per cent science boost
}

London. China has promised to increase its spending on research and development by 12 per cent in the current (1996) financial year, two percentage points more than the planned overall increase in government spending. It has also renewed a pledge to treble spending on science and technology as a proportion of gross domestic product (GDP) by the end of the century.

In a speech last month to the People's Congress, Liu Zhongli, the finance minister, said "greater efforts must be made beginning this year" to reduce expenditure and to pursue a "tight financial policy" aimed at addressing the country's budget deficit.

But he emphasized that the budget for science and technology - currently 0.5 per cent of GDP - would continue to increase. In particular, spending on science and education, will grow by 12 per cent to 10.7 billion yuan (US\$1.28 billion) and 99.4 billion yuan respectively. Both these increases are 2 per cent higher than the overall increase in government spending, which is planned to be 1.2 per cent lower than the increase in revenue. China's budget deficit, which last year climbed by 31 per cent, is projected to increase by a further 26 per cent this year.

Liu acknowledged that the increases in science expenditure came at a time when many departments had "already exerted themselves" to reduce spending. But he emphasized that the extra funds for science, technology and education would be spent more efficiently. "More spending for education and science and technology", he said, "should be used to improve and upgrade existing education and research facilities, instead of increasing projects or new institutes".

In 1994, China spent a total of 22.2 billion yuan on research and development, approximately one quarter of which came from the private sector. The government is aiming to increase industry's share of research and development to at least 50 per cent by 2000 (see Nature 378, 542; 1995). In 1992, China spent 0.7 per cent of GDP on research and development. The country's rapid economic growth has contributed to the decline in this figure. Ehsan Masood

\section{Prospects of power prompt rethink for German Greens}

Munich. As the German Green party arguably the most powerful environmentalist force in Europe - seeks to establish its credibility as a potential coalition partner in a future federal government, it remains split over its opposition to biotechnology and genetic engineering, just as it is over attempts to move closer to the centre-stage of German politics.

Those seeking more moderate policies include Manuel Kiper, spokesman for the party's parliamentary group on research policy. Kiper argues that a blanket ban on biotechnology is inappropriate, both because, he claims, its many benefits - particularly in health and environment - outweigh any environmental threats, and because biotechnology products are already being marketed with the approval of grassroots environmental groups.

But Kiper's position, which he estimates to have significiant support in the party, continues to encounter stiff resistance from the fundamentalist wing, which is arguing against any change of policy. Marina Steindor, the parliamentary group's spokeswoman on health, energetically argues that the party should insist on the withdrawal of all biotechnological products from the market, and accuses Kiper of political opportunism.

Kiper, a molecular biologist by training, says that he is particularly concerned that 'fundamentalism' in the party has been blocking for more than a year a planned party conference on the use of genetically engineered enzymes in washing powder. During this period, other environmental and consumer organizations have reached agreement with the washing powder industry on safety issues and labelling.

Indeed, the parliamentary group appears to agree with Kiper that the party should at least review its position, and a debate on this issue is now likely to take place at the annual

conference in spring next year. The party has already agreed, at its 1996 annual conference last month, to lift a ten-year boycott of computers. The boycott was so out of touch with society that it raised smiles rather than serious support, says Kiper, arguing that the ban on biotechnology will be seen as similarly ridiculous in future.

Another critic is Jens Reich, a molecular biologist at the Max Delbrück Centre for Molecular Medicine in Berlin, who, although not himself a member of the party, was picked as its candidate for the presidential elections two years ago. Reich argues that the fundamentalists' uncompromising

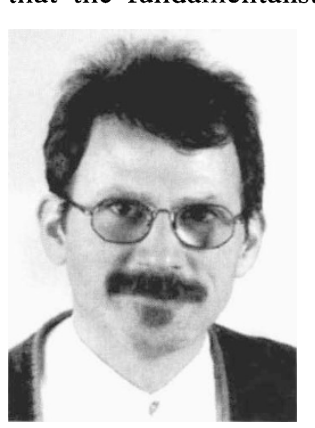

Kiper: argues against ban on biotechnology. \section{main political par-} ties, the ruling Christian Democrats and the opposition Social Democrats, are keen to reverse popular opposition to biotechnology and genetic engineering as part of their efforts to boost economic growth. Scientists notice that pressure groups are now much more prepared to discuss controversial issues rather than dismiss them dogmatically.

At a meeting held last month by Dachema, a company that promotes the interests of Germany's chemical industries, politicians from both the Christian Democrat and Social Democrat parties showed themselves quick to exploit the more tolerant environment. In particular, there was widespread support for the view that attempts to establish a consensus - Germany's traditional political approach - on biotechnology should be abandoned. "In a pluralistic society it is acceptable to live with a bit of dissent," said Wolf-Michael Catenhusen, the Social Democrats' spokesman on research.

Meanwhile, the Greens are preparing themselves for possible power-sharing in a future federal government. They already share government with the Social Democrats in three of Germany's 16 Länder, and after last week's regional elections are likely to join them in a fourth coalition, in Schleswig-Holstein. Conflicts within these coalitions about biotechnology have so far been avoided by an unspoken agreement not to raise the issue; internal arguments have tended to focus on more immediate issues such as transport.

There have long been talks at the federal level between the Social Democrats and the Greens about a possible coalition after the 1998 federal elections. Now the Social Democrats might have a competitor. Two weeks ago, sensitive to the uncertain fortunes of the Free Democrats, the Christian Democrats' current coalition partner, despite their reasonable success in the recent regional elections, Chancellor Helmut Kohl stated that he would also "not rule out" a future coalition with the Greens.

Joschka Fischer, head of the Greens' parliamentary group, is actively trying to make his party attractive to both suitors. But he is aware that, in order to do so, the party will have to shed its extremist image, and that includes abandoning a blanket ban on genetic engineering which, according to recent opinion polls, no longer has public sympathy.

Alison Abbott 